\title{
Electricity Deregulation in CanAda: an Idea Which Has Yet to be Tried?
}

\author{
ANDREW J. ROMAN"
}

The author outlines the factors involved in the "deregulation" of government-controlled industries, highlighting confusion caused by that misdescription. The challenges facing the Alberta and Ontario governments in the fledgling efforts at restructuring their electricity industries are illustrated against a backdrop of lessons derived from the attempted "deregulation" of electricity in California, and from the Canadian experience with airline, telecommunications, and natural gas industry restructuring.
L'auteur donne les grandes lignes des facteurs pris en considération au moment de la "déréglementation» des industries sous contröle de l'État et insiste sur la confusion que cette erreur de désignation a causée. Les problèmes auxquels les gouvernements de l'Alberta et de l'Ontario font face en faisant de nouveaux efforts pour restructurer leurs secteurs de lélectricité sont illustrés avec, comme toile de fond, les leçons tirées des tentatives de "déréglementation" de l'électricité en Californie et de l'expérience canadienne dans les secteurs de l'aviation. des télécommunications et de la restructuration de l'industrie de gaz naturel.

\section{TABLE OF CONTENTS}

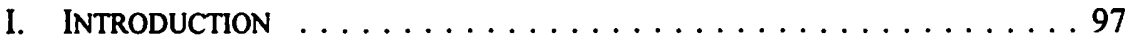

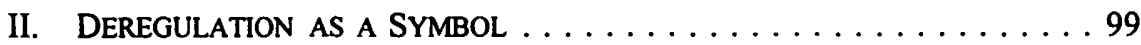

III. Have We TRIEd DeREgulation? $\ldots \ldots \ldots \ldots \ldots \ldots \ldots \ldots 100$

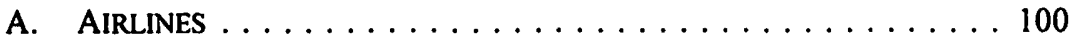

B. TELEPHONES AND TELECOMMUNICATIONS $\ldots \ldots \ldots \ldots \ldots 102$

C. Natural Gas ................... 104

IV. COMPETITION, DEREgulation, AND NATURAL MONOPOLy ..... 104

V. THE TRANSITION FROM MONOPOLY TO COMPETITION ........ 108

VI. DEREgulation has GENERALly MEANT MORE, RATHER THAN LESS INTRUSIVE, REGULATION CONDUCTED IN NEW

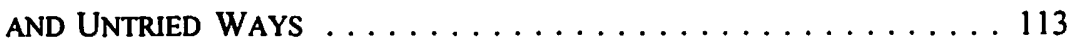

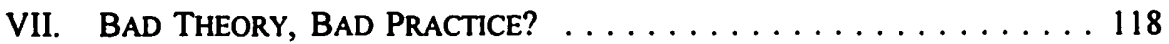

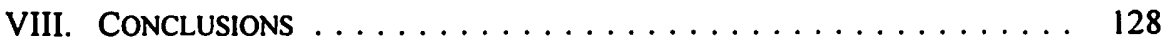

\section{INTRODUCTION}

It seems that scarcely a week goes by without some media coverage of electricity deregulation:

- "California's flawed deregulation process is to blame for skyrocketing energy prices" The Globe and Mail (13 April 2001) B1.

- "Deregulation [in Ontario] has been under discussion for more than three years but is highly controversial because of problems that energy deregulation has caused in Alberta and California" The Globe and Mail (24 April 2001) A4.

Partner, Miller Thomson LLP, Toronto, Ontario. 
- "California decides to raise consumers' power prices" The Wall Street Journal (27 March 2001) B2.

- "One big risk the company, and all generators, face, he said, is the issue of 'government overhang'" TransAlta President Steven Snyder, quoted in The Globe and Mail (26 March 2001) B3.

- " "Regulatory uncertainty is one of the biggest risks facing players in Alberta's fledgling electricity marketplace, industry experts warn" IPPSA News (April 2001) 1 .

What is this controversy over "deregulation" really all about? Is the deregulation of electricity a good idea or a bad idea? Does it depend on how it is done, or is deregulation inherently good or bad?

The central point of this article is that "deregulation" is a shorthand symbol for a multitude of different governmental actions. Most of these have nothing to do with the elimination or near elimination of regulation. Rather, they usually involve different and often more intrusive regulation than previously existed. It does not help us to understand or to evaluate these governmental actions, good or bad, if we label them by what they are not: "deregulation."

As we shall see, in some cases the problems have been caused by politicization, to which the solution would be depoliticization, not deregulation.

In other cases, the problems have been caused by conceptual confusion, such as mistaking "choice of supplier" for deregulation, and confusing simple choice with effective competition through the removal of barriers to entry. For the sake of simplicity, such conceptual confusion will be termed "Bad Theory."

In still other cases, implementation problems have been the villains. For the sake of simplicity, these will be called "Bad Practice."

It is quite common for a jurisdiction to combine both Bad Theory and Bad Practice. If legislators or regulators are unclear about what it is that they are trying to do, it is quite likely that they will simultaneously try to do the wrong things and will implement these plans incorrectly. Faced with such compound sources of error, it becomes particularly difficult for those living in the middle of it to be able to identify what complex solutions may be required.

This is not, and cannot be, a scholarly article. Electricity deregulation is evolving so rapidly that media stories, rather than learned articles in law journals, form much of the written raw material on which this article is based. Also, the writer has been active for thirty years in a practice involving participation in both regulatory hearings and deregulation planning and implementation in several industries, and acting as an advisor to governments and regulators, and as counsel to a variety of clients. The analysis in this 
article is derived more from this experience than from the writer's reading of academic articles.

Nor is this article truly national in scope. In many places the experience examined is from the United States, while the Canadian experience is focused on Alberta and Ontario, the only two provinces that have started seriously to restructure their electricity industries.

\section{Deregulation as a Symbol}

Electricity is not the first industry to have been "deregulated." We have also seen deregulation in industries such as telecommunications, airlines, and railways.

The origins of the deregulation ideology can probably be traced to the Conservative government of Margaret Thatcher in the United Kingdom, a government which introduced radical economic change, making it very unpopular with the highly militant and powerful union movement in that country. Where government ownership of industries was once an important aspect of industry structure, privatization has often preceded or accompanied deregulation. This once radical ideology has now become mainstream, and it has spread to virtually all parts of the world, both developed and developing.

Where state-owned industries have been privatized, unionized jobs have often been lost as the new owners downsized the labour force. Where prederegulation prices were kept artificially low by government action (as in Ontario, where electricity prices had been "frozen" by government fiat for eight years while electricity generation and distribution costs increased) postderegulation prices have usually risen, at least in the short run. Even without privatization, deregulated industries, when faced with competition, have tended to reduce their labour forces in order to cut costs. The reduced employment has been unpopular with workers; the increased prices have been unpopular with consumers.

The simple theory underlying deregulation was that the heavy hand of government regulation was both costly and inefficient. By eliminating regulators, government spending could be reduced and market forces could begin to operate. The result would allow the marketplace, rather than government regulators, to decide how much service to offer, where, and at what price. Similarly, by privatizing government-owned industries, private sector owners could introduce more efficient uses of capital and labour; selling parts of these industries to different owners could create competition among them.

As with most radical changes, deregulation and privatization create winners and losers. Generally speaking, the winners were seen as being the new corporate shareholders; the losers, the employees. As for consumers, there has been a great deal of debate as to whether they are winners or losers. As the writer has argued elsewhere,' it will usually be impossible to determine what would have happened in the same jurisdiction if all other things had been held equal, but if the deregulation had not occurred. Given the decade or

See the writer's paper presented at the University of Calgary, A.J. Roman, "An Overview of Electricity Deregulation" (Restructuring Alberta's Electricity System - How will it Work?, University of Calgary, 19 June 1998) [unpublished]. 
more it would take to make such determination, a sufficient number of other variables would have changed to obscure the answer.

The problem of assessing benefits and costs to consumers is compounded by the fact that deregulation is not a precise term signifying something specific. Rather, it refers to a series of different activities undertaken by government over an extended time period, resulting quite possibly in more, albeit different, regulation as the process evolves. That is why it is sometimes referred to as "reregulation" rather than deregulation.

To call it reregulation is useful to the extent that it clarifies that existing regulation is not being eliminated but merely restructured. The usefulness of the term ends there, however, because without more, it does not tell us what new features the restructured regulation will provide and why.

Since "deregulation" has no precise meaning, there is nothing to prevent politicians from characterizing their activities as being "deregulation" if they believe that such a description will be popular. Similarly, there is nothing to prevent opposition politicians or the media from being critical of governmental activities by describing them as "deregulation" if they believe such a description to be effectively critical. Whether the governmental activities in question create more, less, or merely different regulation is seldom considered.

"Deregulation" has become a symbol the political right loves to love and the left loves to hate, with neither side having anything specific in mind. Debates about the merits of deregulation are frequently emotional, but ultimately inconclusive because the parties do not mean the same thing when they talk about deregulation. Because the term carries with it so much rhetorical baggage, yet so little substance or precision, it should probably not be used at all.

\section{HaVe We TRIED DeRegulation?}

"Deregulation" has been widely reported as having been applied to a number of industries in Canada and the United States, including airlines, railways, telecommunications, natural gas and, now, electricity. But is what has occurred in these industries really been "deregulation"?

\section{A. AIRLINeS}

Let us consider briefly what happened in so-called airline deregulation. ${ }^{2}$ What was deregulated? What was the result?

None of the countries that deregulated airlines removed regulation from the core safety aspects. Aircraft can still only be flown by licensed pilots. Aircraft must still meet stringent safety standards. At airports, time intervals between aircraft taking off and

2 For a more detailed analysis see A.J. Roman \& J. Todd, Airline Deregulation in Canada: Why it Failed (Ottawa: Public Interest Research Centre, 1989). 
landing have not been deregulated. What then was deregulated? The right of airlines to fly between particular city pairs, to add new routes and to abandon old ones without any regulatory approval, and the right to charge whatever fares the airlines wanted to charge.

Despite these steps, the government still controlled airport gates ${ }^{3}$ and takeoff and landing slots. The best of these gates and slots have historically belonged to Air Canada. This special status for Air Canada has continued to serve as an effective barrier to entry for competitors.

Moreover, through the activities of the Mergers Branch of the Competition Bureau there was still governmental control, which could have prevented the rapid decrease in the number of airlines in Canada. Instead, by allowing a number of important mergers right after deregulation, the government permitted a significant reduction in the number of competitors.

Another important aspect of airline competition is the ability to attract capital. Pools of venture capital in Canada tend to be rather limited. New, start-up airlines require large amounts of capital to purchase modern aircraft and to withstand several years of initial business losses while the airline builds up its clientele and goodwill. An obvious source of access to capital is the sale of shares to foreign investors, yet federal government policy imposes stringent limitations upon foreign ownership, thereby limiting the number and vigour of potential new competitors.

Finally, foreign airlines are another potential source of competition. Such competition is effectively precluded on domestic routes because foreign airlines are not permitted to drop off or pick up Canadian passengers on flights within Canada. For example, a US owned airline cannot fly from Chicago to Calgary and pick up passengers in Calgary for transportation to Vancouver. This reduces competition between Calgary and Vancouver.

Looking at the airline situation described above, it seems clear that the sphere of continuing regulation is substantially larger than that of deregulation. Thus, although we talk about airline deregulation, there are still numerous, rather high barriers to competitive entry, most of them created or maintained by government action.

What has been the result? In the last few years we have seen two major airlines, Wardair and Canadian, and recently, the small new airline, Roots, disappear through mergers into Air Canada. Air Canada now controls virtually all of the domestic Canadian market.

The best cartel is a good merger. Rather than conspiring with a competitor to allocate market shares or fix prices, constituting criminal activity likely to result in enormous fines and lengthy jail sentences, why not just buy the competitor? This is entirely lawful ${ }^{4}$ and will achieve an even better result because eliminating the competitor prevents any future

This control has now been delegated in several major airport locations, including newly created nongovernmental airport authorities which operate, but do not own, the airports. 
return to competition if the cartel is detected and its members prosecuted. Air Canada has used this merger strategy with great success.

While there remains a choice of airlines on many international routes, there is little or no choice on most domestic routes. More important than the notion of "choice," however, is "competition." The two are not the same.

An industry can be served by an uncompetitive duopoly, which still provides the optics of choice. However, as the Competition Bureau has indicated in its Merger Guidelines ${ }^{5}$ (adopting the orthodox view of economists that it is effective competition we seek, not merely the appearance of competition), effective competition requires a number of competitors - typically, at least five competitors of approximately equal size in a market. ${ }^{6}$ One giant, dominant player with four or fewer other entrants will probably not result in effective competition because the dominant player will be the price leader while the minor players will not be strong enough to threaten or discipline the dominance of the leader. This notion of effective competition is important not only for airlines but other industries, including electricity generation.

\section{B. TELEPHONES AND TELECOMMUNICATIONS}

The deregulation of what used to be called the telephone industry, and is now called telecommunications, was not introduced by government at all but, paradoxically, by the federal regulator, the Canadian Radio-Television and Telecommunications Commission ("CRTC"). It is difficult to say precisely when this process began, but a fair characterization would be prior to $1980 .^{7}$

The regulator introduced changes because evolving technology made them possible. Thus deregulation became economically advantageous for consumers. Nevertheless, there was a strong tendency on the part of the powerful regulated industry to resist the CRTC's efforts to introduce competition. Opposing this powerful industry was a courageous act for the regulator as an institution and for the commissioners as individuals. This courage runs contrary to the stereotype of the regulator as a supporter of monopolies, a stereotype advanced by many would-be deregulators in order to create the perceived necessity to rescue captive consumers by offering them deregulation.

Director of Investigation and Research, Competition Act, Merger Enforcement Guidelines (Supply and Services Canada, 1991).

- This is a rough rule of thumb, not a strict definition. In markets where relatively little capital intensity is found, permitting easy entry and exit, the market may be readily contestable and thus effectively competitive with fewer than five participants. In other cases where capital intensity is high and competition among competitors may be only partial, more than five participants may be required. A good example of the former may be electricity retailing; a good example of the latter may be airlines, where there may be five airlines in a country, but in any particular geographic region there may be relatively minor overlaps among their routes.

7. In one sense, telecommunications deregulation was initiated by CNCP Telecommunications (and others) when applications were submitted to compete with Bell Canada. While CNCP Telecommunications (and others) did do this, it was the CRTC that responded in a manner that made deregulation possible. The commission could have decided it had no statutory or policy mandate to change the status quo and left the matter to Parliament. 
It is difficult to identify precisely when the process of creating competition in telecommunications began, but early in the process was competition in "terminal attachment," the right to attach telephone handsets and other equipment, not sold or leased by the telephone company or its affiliates but by their competitors, to the telephone company's lines. ${ }^{8}$ Another major step was the introduction of competition in longdistance services through alternative competitive carriers and resellers. ${ }^{9}$ Finally, we have arrived at the stage when the regulator has permitted competition in local or basic service $^{10}$ - probably the last frontier.

It is important to recognize that what has happened in telecommunications is not deregulation as such, but regulatory forbearance. The regulator has remained in place and has initiated and continues to regulate competition. When this regulated competition reached a level regarded as viable, the CRTC used its statutory power to forbear from regulation" so long as it believed effective competition existed. If market conditions cause effective competition to deteriorate and to become ineffective, the CRTC retains the statutory authority to reintroduce more stringent regulation.

In recent years as broadband technology has developed, fibre optic lines have been constructed by a number of companies, ${ }^{12}$ some of which do not provide end-to-end telecommunications service to consumers, but merely sell or lease their fibre capacity. The growth of the Internet and e-commerce has provided a considerable stimulus to this industry. For now the fibre segment of the industry appears to be competitive, but this may not be for long.

As in the airline industry, telecommunications companies have become fewer in number through failures, acquisitions, and mergers. There appears to be a trend towards greater concentration in this industry, despite the best efforts of the CRTC. ${ }^{13}$

This raises an important issue for the restructuring of "network industries," defined as industries where services are provided across a wide geographic area in a network in which people in one part of the network need to connect or communicate with people in other parts of the network. In airlines one sees this tendency in interconnecting flights and the use of a hub and spoke pattern of dispatching aircraft. In telecommunications the value of the network to customers is increased in proportion to the customers' ability to reach a growing number of other customers in a growing number of locations. In electricity,

Altachment of subscriber-provided terminal equipment. Telecom Decision (23 November 1982). 82-14 (C.R.T.C.).

Competition in the provision of long-distance voice telephone services and related resale and sharing issues, Telecom Decision (12 June 1992), 92-12 (C.R.T.C.).

Local competition, Telecom Decision (I May 1997), 97-8 (C.R.T.C.).

This need not be an all-or-nothing choice. The CRTC can partially forbear from regulation or use various techniques of light-handed regulation: Telecommunications Act, S.C. 1993, c. 38, s. 34(2). Some of these are electric utilities or their affiliates.

This trend has been accelerated by so-called "convergence" with telecommunications companies or their affiliates acquiring large broadcasting and newspaper conglomerates. Whether the convergence element of these acquisitions is significant, or whether these companies are creating nothing more than diversified conglomerates, remains to be seen. 
integrated transmission grids covering large areas of a country or a continent can enhance the reliability of everyone's service.

\section{Natural GaS}

The "deregulation" of the natural gas industry in Canada probably began around 1985. Prior to that gas prices were regulated by both levels of government, and pipelines tended to operate as monopolistic suppliers and transporters of natural gas, delivering the gas to monopolistic local distribution companies ("LDCs"). In essence, it was a market of supply-aggregators and demand-aggregators.

During the mid-1980s and 1990s an active and very competitive natural gas market evolved. Producers and end-use customers began negotiating a myriad of supply and sales contracts ranging from daily spot transactions to multi-year long-term contracts. Gas prices became transparent. Marketers at all levels became active in the marketplace and began competing with LDCs for customers. Proponents argued that consumers had benefited from "deregulation" by having choices. Utility boards began considering and implementing new rules and regulations (reregulation) to deal with wholesale and retail end-user concerns about price, security of supply, and the obligations of the LDCs to serve end-users who opted out and then sought regain access to the LDCs' services. Legislators, reacting to concerns regarding market reactions and conditions, showed readiness to enact new legislation or amend existing acts. In Ontario, at the same time as the entire electricity legislation was being restructured, the Energy Competition Act, $1998^{14}$ was enacted to facilitate natural gas reregulation. However by then much of the difficult work had already been done by the regulators.

"Deregulation" of natural gas in Canada meant the introduction of competition by provincial regulators in all but the transportation of natural gas by "monopoly" pipelines and LDCs. ${ }^{15}$ Although pipelines and LDCs remain regulated by utility boards or energy boards, transporting natural gas under regulated tariff structures and operating rules, some benefits have emerged in that end-use customers may have some choice as to the level of transport they will contract for, and possibly, which pipeline they will use. The interesting fact about gas competition in Canada, like telecommunications competition, was that it was initiated, developed, and implemented by the regulators not by legislation. As with telecommunications, this is a startling paradox to those who detest regulation: deregulation that has worked was created by regulators not by politicians.

\section{Competition, Deregulation, and Natural Monopoly}

Competition (as distinguished from mere choice of suppliers in an oligopoly) only begins to become effective when there are several suppliers; increased effectiveness, 1998, partially in force).

is In this context "monopoly" refers to a particular route or alignment. There may be more than one pipeline transporting gas, e.g., from northern fields to southern markets, and these may compete to some extent. 
generally speaking, occurs as the number of market participants increases. Eventually a point is reached when the entry of the next participant makes little or no difference to the effectiveness of competition.

Some industries, or parts of industries, are "natural monopolies." About twenty to twenty-five years ago we had, throughout Canada and the United States, numerous regulated industries - telephones, electricity, and gas, to name three - that were considered natural monopolies. The reason for describing them this way, generally, was because economies of scale continue regardless of how large the enterprise grows (or at least up to the size of the existing market - i.e., cost is always lower with one firm in the market than two or more). ${ }^{16}$ These economies were often the reflection of the impracticality of duplicating costly and unsightly infrastructure, such as several sets of telephone or power lines going down the same street.

Although we could potentially have several sets of telephone or electricity lines going down the same street parallel to each other, ${ }^{17}$ if competition was more important as a social goal than avoiding the visual mess this would create, the first proposition in the theory of natural monopoly would mitigate against this. Since economies of scale continue almost indefinitely in this theory, the proliferation of facilities would result in splitting the business between two or more market participants, each of which would be less efficient than a single provider. This would result in higher costs as a result of competition, not lower costs. The greater the number of competitors in the market, the higher the prices customers would face. Under this theory, in a natural monopoly situation, monopoly is good and competition is bad, subject to one important requirement: effective regulation of the monopolist to avoid the monopoly abusing its monopoly power. A monopoly maximizes profit by restricting output and raising the price above the competitive price; that is, above the price needed to recover its costs, including "normal" profit. Effective regulation controls this. Effective regulation should also prevent a monopoly from becoming so inefficient and wasteful, without the spur of competition to keep the enterprise lean, that the benefits of the natural monopoly would be compromised or lost.

It is also clear that there are many regulated industries - the professions, such as law, medicine and accounting, as well as a variety of trades are good examples - where it is thought that no natural monopoly is required to maximize efficiency and minimize prices to customers. Some have argued that such industries are regulated for the benefit of those subject to regulation as much or more than for the benefit of the public because they create barriers to entry that restrict competition from persons who are not members of the "union."

This is important because the normal situation is that economies of scale continue as an enterprise grows larger only up to an optimal point, and then they become diseconomies of scale. If this were shown on a graph with cost per unit on the vertical axis and number of units on the horizontal axis, the plotted line representing the cost curve would appear to be U-shaped. With a natural monopoly the line would continue to trend downwards to a minimum cost per unit, and it would remain at that level until a new technology or other important structural change affected the situation. 
For several decades, if not most of the twentieth century, natural monopolies were regulated through elaborate and lengthy adversarial proceedings before a statutory regulator, typically called a public utilities commission or an energy board in most North American jurisdictions.

Eventually, in the late 1970 s and early 1980s, the possible overuse and misapplication of the theory of natural monopoly was seriously questioned. In some cases, technological changes had reduced or even eliminated the natural monopoly; in others, the "bundle" of services offered by the monopolist included separable services that were potentially competitive. In still other cases, the natural monopoly remained, but traditional regulation failed to minimize costs. Hence traditional rate-of-return regulation has evolved into socalled incentive or price cap regulation. During litigation in the United States to break up AT\&T, a number of economists testified that the economies of scale in AT\&T had been overestimated and that AT\&T had gone past the point of economies of scale into diseconomies of scale. The logical conclusion was that breaking up AT\&T into smaller and potentially competitive units would be in the public interest because costs, and prices to customers, could be lowered in this way. As is well known, the US court did break up AT\&T to create the so-called "Baby Bells."

The scope of natural monopoly also began to be questioned. Large regulated monopolies were, in earlier years, seen as providing a single service: end-to-end telephone service, electricity service, gas service and so on. Eventually new questions were asked about whether all of these vertically integrated services or products were necessarily parts of a natural monopoly, or whether the natural monopoly, if it existed at all, was only part of the business, while the rest was potentially competitive. Under the latter theory, by breaking up the business into separate smaller businesses, some, if not all of these could be provided competitively.

This is not the same as breaking up a single corporation into several smaller ones through the operation of the antitrust laws in the courts. Only the United States had antitrust laws that would permit such radical destruction of company share values by a single judge. Rather, only certain parts of a formerly monopoly business would be opened to competition. The name given to this step - quite incorrectly, as we shall see - was "deregulation." The name was chosen because if a business or part of a business was no longer to be treated as a monopoly but be subjected to competition, then it would no longer need to be regulated as a monopoly. Hence we would have "deregulation."

At around the same time in the UK, the Thatcher government also began to question the application of the theory of natural monopoly. But the UK situation was made more complex because many large natural monopolies (telephones, electricity, and gas among them) were state-owned enterprises, unlike in the United States where government ownership was the exception. The UK, therefore, had to consider privatization as part of its economic reforms in addition to changes to its regulatory structures.

Canada was influenced by both the UK and the American models. Like the United States, our federal government was not an owner of the telephone, gas or electricity industries; but like the UK, most of the Canadian population was served by publicly 
owned utility enterprises. In telephones the ownership situation was mixed: in different provinces telephone companies were privately owned or owned by provincial and even municipal governments. ${ }^{18}$ Outside of Alberta electricity utilities were owned by provincial and municipal governments. Canada, therefore, in most provinces and with most natural monopolies, had to consider both public ownership issues and regulatory issues when attempting to manage the transition from a monopoly industry structure to a competitive or partially competitive industry structure.

This created an extra layer of complexity because in so many situations government was the owner, the legislator, and the regulator of the utility. A regulated utility that was subject to significant stress by its regulator could always pressure its shareholder for relief, and the pesky regulator creating the problem could find herself disappointed when the term of her appointment expired. Or, as in Ontario, the "regulator" of Ontario Hydro, the Ontario Energy Board ("OEB"), had no meaningful regulatory authority over the utility. Its powers, prior to the so-called "deregulation" in 1998, were limited to hearing, at the minister's request, a proceeding into electricity rates at the end of which the OEB could merely make a recommendation, not a decision. The Ontario Hydro board of directors had the power - exercised at times almost gleefully - to ignore the OEB's recommendations.

In the telecommunications industry, as the theory and practice of deregulation evolved, telephone service was seen as the provision of a series of different products and services: private lines, terminals (handsets, etc.), long-distance (with several subproducts), and even basic or local service. Over time attempts were made, with varying degrees of difficulty, to make each of these competitive. The old monopoly telephone service was seen as having evolved like the Cheshire cat in Alice in Wonderland. As more and more of it disappeared, in the end all that was left was the cat's smile.

In the gas industry, since 1985, the sales function has been separated from transportation, as if they were two separate industries - like wheat farming and grain transportation. The upstream sector of the gas industry was, and remains, competitive.

Similarly, electricity services can conceptually be separated in a variety of ways. The first and most obvious split is along functional lines: generation, transmission, and distribution. Generation is seen as competitive, while transmission and distribution are seen as natural monopolies because they are the classical "wires" businesses. Another approach lies in separating the delivery of the commodity via the wires (the transportation component) from its sale (retailing).$^{19}$ As well, electricity itself can be seen as having several products, such as green power, ${ }^{20}$ voltage stabilization, baseload, peaking power, $e t c$., with potentially different suppliers.

Including Edmonton, Prince Rupert, Thunder Bay, and a number of smaller municipalities such as Kenora, Cochrane, and Dryden.

19 A similar distinction was made in the gas industry, the regulation of which was restructured before electricity. 
Before leaving this discussion of competition, deregulation and natural monopoly, it is important to recognize that the theory of natural monopoly is just that: a theory. Also the theory that an industry which for the better part of a century has operated as a monopoly can be turned into an effectively competitive industry is also just a theory. Neither theory is demonstrably true or false with any scientific certainty. If we could develop a large enough sample size of jurisdictions (perhaps 200 to 300 ), each of which was substantially similar in size and demographics, we could then conduct a scientific experiment. Holding all other things equal, we could give half of these jurisdictions a regulated electricity monopoly. In the other half, we could deregulate the monopoly to permit competition. After several years of such scientific experiment we might be able to draw a conclusion as to whether deregulation "works." But this option is not available to us in the real world.

In the real world we have a large number of variables occurring simultaneously, making cause and effect relationships difficult to resolve. For example, the reduction in long-distance telephone rates over the last two decades has been truly remarkable. Coinciding with this cost reduction were two factors: the introduction of competitors and new technology in switching and transmission. The dramatic reduction of switching costs came first. Switching costs were reduced by the change in technology from mechanical and electromechanical switches to successively more powerful electronic switches. Today these electronic switches are essentially computers, which have benefited from the same sort of improvements in productivity as have chips in personal computers. More recently the cost reduction in transmission through the replacement of copper with fibre optics (high capacity) has provided the most significant saving in long-distance costs. The difficult question to answer today is whether the major factor in the price reduction was the introduction of competition or the vast improvements and savings in switching and transmission technology. All we can say with any certainty is that the reduction in longdistance prices coincided with the introduction of competition and the reduction in switching and transmission costs. What would have happened but for the introduction of competition, or the reduction in switching and transmission costs, is anyone's guess.

\section{The TRANSITION FROM MONOPOLY to COMPETITION}

When an industry has been substantially monopolistic - by definition, served by only a single supplier - for many decades, it is sheer hubris for any government to believe that, all considerations of technology, industry structure, etc. aside, it can simply "create" competition by announcing a policy of "deregulation." Government policy cannot, by itself, create a healthy competitive market, even with the assistance of legislation, any more than a government can repeal the laws of economics.

If the government's theory that there is no more natural monopoly in a particular industry (e.g., in electricity generation) is wrong - and only trial and error can determine this - there will be a strong tendency for the industry to revert, first to oligopoly (perhaps regionally, rather than nationally) and then to monopoly. Today it is not at all politically correct to mention the possibility of natural monopoly, even in an economy as large as Canada's, because this implies the possible existence of market failure in some markets, a thoroughly unfashionable idea. Market failure implies the need for regulation, 
another unfashionable idea in this era of belief in the infallibility of markets without exception, and a belief in the redundancy of regulation.

In reality, however, if deregulation is introduced into industries in which there has not traditionally been healthy competition, there is a serious risk of failure. This failure could be for at least three reasons.

First, the elements of natural monopoly may have been much stronger than the government and its advisers contemplated; hence the natural equilibrium in the industry is to revert to monopoly. Second, although the market could have been competitive, the transition to competition required a much longer time period and much more draconian action (e.g., forced divestiture of generating assets by major electric utilities, possibly requiring compensation for a "taking" of private property; privatization of provincially owned generation utilities to several purchasers to break up the concentration of ownership) than the government was willing to undertake. Third, a failure to consider what is required to keep supply and demand in balance during the transition may result in sharp price increases and political panic in responding to them. We shall consider each of these three failures below.

From the foregoing analysis, it should be clear that the existence of regulation is not necessarily, by itself, a significant cause of the inefficiency that is believed to exist in a monopolistic industry. It follows, therefore, that "deregulation" is not necessarily the solution to anything, even when it is managed well. Furthermore, it is quite possible that in the process of attempting to restructure industry through "deregulation," the law of unintended consequences will apply, and the postderegulation situation will be even worse for consumers than the prederegulation situation. Indeed, this is a quite likely result unless there is adequate planning for the transition from monopoly to competition.

A precondition to such planning is a thorough understanding by legislators of the technology and the economics, in their own jurisdiction, of the industry they are proposing to restructure; in particular, there should be an understanding of all of the barriers to entry of new competitors, of which the regulator may not be one. In the case of telecommunications, for example, the CRTC has been far more instrumental in initiating and managing the transition to competition than has Parliament. In the United States the Federal Energy Regulatory Commission ("FERC"), in its landmark Orders 888 and $889^{21}$ and follow-up orders, has shown major initiative in enhancing competition through the creative use of its power to regulate interstate commerce in electricity. Similarly, FERC 
Order $636^{22}$ in the United States and the National Energy Board decision in RH-5-85 $5^{23}$ were key decisions in the unbundling process for the natural gas industry. For the legislators planning deregulation, it is necessary to understand the technology employed by the industry, the economies of scale (and of scope if more than one product is involved because a vertically integrated industry capturing economies of scope such as electricity generation, transmission, and distribution may have lower costs than an industry structure without such vertical integration), what factors in adjacent jurisdictions may have an impact, and a whole host of other factors.

Few, if any, legislatures have undertaken such detailed economic analysis. Generally speaking, the legislative technique has been to leap first and to look afterwards, hoping for a safe landing. In some cases, for a variety of serendipitous reasons, the initial results, at least, have not been too bad. In others, such as the case in California, the lack of forward thinking and planning has proved disastrous.

Let us now consider the first possible reason for the failure mentioned above: the continued existence of strong elements of natural monopoly. Rather than looking at electricity in isolation, it is important to remember that much of the impetus for electricity deregulation was the perception that something called "deregulation" was successful in telecommunications, airlines, and gas and, therefore, would also work in electricity. Let us consider the applicability of experience in these other industries to electricity.

Before becoming too self-congratulatory about the success of deregulation in telecommunications, it is worth noting that through repeated mergers, in some cases to avoid a competitor from failing, the telecommunications industry has become much more concentrated again in recent years. If competition in long-distance service, for example, is not in the process of failing in Canada, it is certainly not healthy. Neither the federal government nor the CRTC have overtly acknowledged that competition is in serious trouble in large sectors of the telecommunications industry. Instead the CRTC has been holding hearings on "convergence," as if this was synonymous with "conglomeration."24

"Pipeline Service Obligations and Revisions to Regulations Governing Self-Implementing Transportation Under Part 284 of the Commission's Regulations; Regulation of National Gas Pipelines After Partial Wellhead decontrol" (8 April 1992), Docket Nos. RM91-11-000 and RM8734-065, online: FERC <www.ferc.fed.us/news/rules/pages/order636.htm> (date accessed: 2 January 2002).

23 TransCanada PipeLines Limited (May 1986), RH-5-85 (N.E.B.).

24 Convergence, like deregulation, is so vague and used so differently by different commentators that today it can mean almost anything. Originally developed to describe a coming together of two technologies (broadcasting and telecommunications) into one via satellites and smaller receiving dishes, or bandwidth permitting voice and data, the concept has recently been expanded, if not totally changed, to include mere marketing convergence. This latter notion permits conglomerates to rationalize owning newspapers, television networks, and wires to the CRTC and the Competition Bureau. It is not clear why there is more convergence in owning a telephone network, a broadcasting network, and newspapers than there is in owning a gas pipeline, a gas distribution business, and an electric utility. The benefits of such conglomeration have more to do with financial strength, infrastructure ownership, and the reduction of direct or indirect competition than they do with large economies of scope and scale. 
The second failure, a longer than expected transition period and more draconian action, is illustrated by airline deregulation in Canada. This has led, in a few short years, to a virtual monopoly by Air Canada over many city pairs. In the absence of a federal airline regulator, the government has tried to make do with an ombudsperson and by stretching the normal role of the Commissioner of Competition from reviews of mergers and anticompetitive practices into an all-purpose airline watchdog and quasi-regulator. The government's airline policy can only be based on the belief that viable, effective competition in the airline industry in Canada will eventually arise, despite ownership restrictions that prevent non-Canadians from starting and owning an airline in Canada, and despite restrictions against foreign airlines picking up passengers on flights between city pairs in Canada. This situation fully illustrates the consequences of a policy of economic nationalism overriding the analysis and correction of government-createdbarriers to entry. In other words, airline deregulation that permits and effective competitive market in Canada may require the removal of these regulatory barriers to entry.

As with telecommunications and airlines, electricity deregulation may require for its completion - that is, the replacement of a non-competitive structure with effective competition - the breaking up of large-scale generation enterprises into numerous smaller units and, if the monopolist is government owned, as in most Canadian provinces, the privatization of these monopolies and simultaneous breakup into smaller units. These may be the essential transitional requirements, without which we are taking no more than a couple of timid steps down the path toward competition. If the journey begins and ends with reducing regulatory barriers to entry (where they exist) and fails to tackle the domination of the industry by one giant participant, there is a high likelihood that the transition will not be made. We may dispense with some degree of regulation - although, as we shall see, the reverse is often the case - but this is unlikely to accomplish anything of significance because it does not bring us much closer to the creation of an effectively competitive market.

In industry restructuring, as in golf, it is important to keep one's eye on the ball. The ball in this case is not deregulation, but competition. Deregulation is merely one means to achieve competition, but it is not the end itself. The end is an industry structure with effective competition that is viable in the long run. The means to that end is the removal of all significant barriers to entry, one of which is regulation that has an anticompetitive effect. If this transition takes one or two decades, as it well may, we have to plan for what will happen during the transition.

Another way of looking at this issue is that after almost a century of monopoly in electricity, it may be necessary, as it was in telecommunications, to level the playing field and then to leave the game alone. Governments find this very distasteful because it necessarily involves weakening the strong in order to strengthen the weak. Where, as in Ontario's deregulation, the government owns the strong and must repay its $\$ 38$ billion debt, ${ }^{25}$ it will be reluctant to do anything that might impair its ability to make the repayment. In Alberta, where the strong are privately owned, the government did not 
directly weaken the three large electricity generators through forced divestiture, as was done in some other jurisdictions, but attempted to create partial competition through a complex and essentially untried process of auctioning power purchase arrangements ("PPAs"): long-term contracts for the right to sell a generator's electricity to others. Whether this has effectively levelled the playing field in Alberta remains to be seen.

The third cause of failure is the lack of planning necessary to keep supply and demand in balance. Probably the most dramatic example of this case would be California's recent experience, although Alberta has not been able to avoid these difficulties entirely. The problem of lack of supply has not occurred to nearly the same degree with natural gas deregulation. A primary reason is that the upstream of the supply side is competitive, giving the gas industry a multitude of decision-makers on the supply side. This has not been possible in the electricity monopolies found in most Canadian provinces or in the oligopoly found in Alberta. There are other reasons, discussed below, which explain why the experience of the relatively easy deregulation of the natural gas industry will not be so easily replicated in electricity.

The major problem with the California electricity deregulation was that after the state had moved along that path for several years, it became clear that little or no attention had been paid to keeping supply and demand in balance. For a variety of reasons, no significant new generation capacity had been constructed while demand continued to increase. In the absence of a commensurate increase in supply, only imports can meet the supply deficit. However, imported electricity comes at a higher price, not only because suppliers need to recover transmission losses, but also because imported power will be bid into the electricity exchange (which operates like a stock exchange) at whatever price the market will bear. The only solutions to ever escalating prices are the construction of more domestic capacity (which is not easy under California's environmental regulation or uncertain economic and political climate for electricity investors) or the reduction of consumer demand.

The California Legislature, however, did not permit market forces to operate as one would expect in a so-called deregulated market. Rather, lacking real conviction in the efficacy of markets, or being unwilling to face the political heat arising from the rapid escalation in electricity prices, the legislature attempted to repeal the laws of supply and demand by legislating a cap on electricity prices. Thus rapidly growing demand arose from the lack of an appropriate price signal. This was the result of price regulation by legislators, not by a failure of "deregulation."

Prior to deregulation, electricity prices were set (directly or indirectly) by regulators. Such regulators normally have decades of collective experience in this task. In Califormia the legislators took this regulatory role away from knowledgeable and experienced regulators and gave it to persons with little understanding of economic regulation: themselves.

In short, this was not "deregulation" but much more intrusive regulation, carried out by inexperienced rather than experienced regulators. It was not that deregulation failed in 
California; it was that it was not tried. In fairness then, it was regulation, California-style, that failed, and not deregulation.

It failed primarily because the cap on retail electricity prices set by the legislation was set on the "wires" utilities, not on the generators, and was fixed at a price well below the cost to the utilities of purchasing and distributing that electricity. This meant that these utilities were driven into bankruptcy, or to its very edge, not by deregulation, but by legislated prices that were unrealistic. The legislation was politically popular, as it appeared to prevent higher prices for a while, but the fantasy that legislation could hold prices below costs indefinitely was unsustainable. The cap appeared realistic when it was first set; what the legislature failed to recognize was that with the price of electricity constrained, demand would not be moderated so as to achieve an equilibrium at a reasonable price. Once this became evident, rather than removing the constraints immediately, the Legislature simply ignored the problem and hoped it would go away by itself. Whatever else this legislation was, it was not deregulation. It was simply politicization of regulation.

Since the financial collapse of the utilities, the Califormia Legislature has attempted a degree of depoliticization by allowing the California Public Utilities Commission to permit higher prices to be charged. It may be that these higher prices still do not recover costs, and they may have to be raised again. But it also shows that some degree of rate regulation is back and out of the closet. It appears that California has decided that the unregulated market does not work and has gone full circle back to regulation. What political "spin" will be put on this retreat will be interesting to watch.

\section{Deregulation has Generally Meant More, Rather than LESS INTRUSIVE, REgulation CONDUCTEd IN NEW AND UNTRIED WAYS}

The California electricity experience has shown that "deregulation" can lead to more, rather than less intrusive, price regulation executed in new ways.

In the twenty-three American states in which electricity deregulation has been legislated, rates were capped or frozen, regardless of electricity generation or transmission costs: in some cases for three to four years, in others, for as long as a decade. Despite these attempts to set rates by legislation, a rate increase is pending or has been approved in almost half of these states, ${ }^{26}$ and many of the remainder (if not all of them) will probably have to follow suit.

As well, system reliability problems caused by transmission bottlenecks may affect both reliability and electricity costs in certain states. Deregulation does not directly cause a reduction of transmission planning, investment and maintenance, but it may do so indirectly, as vertically integrated utilities are broken up into regulated "wires" companies 
and unregulated generation companies. ${ }^{27}$ It may be that economies of scope are lost, thereby raising the cost of providing each product, generation, and transmission.

It is important for policy-makers to recognize that electricity generation and transmission are, in essence, substitutes for each other rather than different products in different markets. This is a key difference between gas and electricity. Unlike gas, which must be found by exploration and is in a limited number of locations, and it then must be transported to customer markets, electricity can be generated almost anywhere the customers are located. Natural gas, which is extracted from the earth, is analogized to mining; electricity generation is like manufacturing. That is why no one will invest in new generation if it is less expensive to transmit electricity from a remote location with sufficient unused capacity to provide security of supply. For example, there are numerous large electricity generating stations near my home in Toronto to supply me with electricity; my supply of natural gas, however, comes via pipeline from Alberta.

Where two products, such as generation and transmission, are such close substitutes for each other that increases in the cost of one will result in greater consumption of the other, and where the two products are also very similar in their product functions, ${ }^{28}$ like transmission and generation ${ }^{29}$ of electricity, they could, in a real sense, be seen as constituting a single market. The market for generation is not so fundamentally different from the market for transmission, as exists between pipelines and others in the gas industry. Most electricity consumers ${ }^{30}$ do not know or care (apart from possible environmental concerns) whether the electricity they take from the grid comes from a generator nearby or one further away, and their delivered price of electricity is more a function of generation costs than wires costs (generation accounts for roughly 70 percent of the cost of electricity; transmission and distribution account for 30 percent). That also explains why there tend to be rather small margins for the sellers of electricity, which in turn causes most consumers, large and small, to buy directly from utilities rather than intermediaries.

This fundamental difference between the gas industry and electricity industry results in it being much more difficult to be confident that reliable and efficient supply can be assured without regulatory intervention by deregulating electricity generation in the same way as the non-transportation part of the natural gas industry was deregulated. Vertical

The writer has developed this theme in greater depth elsewhere: A.J. Roman, "Legal Responsibility for Reliability in the New Competitive Electricity Markets in Canada" (2000) 20 IEEE Power Engineering Review 10.

Petroleum and natural gas have a relationship of substitutability to a substantial extent for uses like heating water, but petroleum comprises a number of different product uses ranging from pharmaceuticals to lubricants.

29 Both of which provide a similar product to the end-user: a difference in electrical potential between negative and positive poles. Unlike the gas industries, which search for, discover, extract, aggregate, store, and transport gas molecules long distances to customers, electricity industries do not actually transport anything. Electrons do not physically move down wires to customers. 
integration in electricity may be much more important to cost reduction and competitiveness than it is in natural gas.

Electrical utilities that are vertically integrated engage in cost minimization exercises through integrated resource planning ("IRP"). This means that they examine the cost of delivering growing electricity supply to each part of their service territories, particularly those in the midst of rapid growth. If it appears to be less costly, over the anticipated lifetime of the asset, to build a new generator at a particular location, it will be built there; if it appears less costly to build transmission to that location and to increase the output of a generator elsewhere in the system, generation will be expanded rather than transmission. Canadian provincially owned utilities are all vertically integrated and have made extensive use of IRP. ${ }^{31}$

Once the transmission companies have been separated from the generation companies, IRP may be reduced or may become very difficult; that is because new competitive generators, or companies that self-generate, do not take directions from the transmission utility as to whether or where they should construct new generation. Generation and transmission built separately may each be less efficient than if they were planned as an integrated system by the same organization.

Transmission siting and construction occurs slowly and in large chunks; whereas the new, smaller, gas fired generation ${ }^{32}$ is built quickly and inexpensively, reducing the need for transmission and, therefore, the attractiveness of investing in new and expanded transmission facilities. If the trend towards distributed generation continues with smallerscale gas generation and, eventually, fuel cells in every home, large scale and lengthy transmission lines could become major stranded assets. Fear of this long-term technological risk may result in reduced investment in transmission, causing larger urban centres to be increasingly isolated from the competition of generators elsewhere, which enhances the market power of local generators, reducing competition and increasing in prices. This could be an unintended consequence of creating greater distance between generation and transmission to make generators more competitive.

The experiences in Alberta and Ontario, whose electricity restructuring efforts have generally lagged behind those in the United States, have not been nearly so extreme as in parts of the United States, but have been directionally similar.

Alberta has not really deregulated. It now has a greater number of regulatory bodies than before. ${ }^{33}$ Some of the functions formerly carried out by industry members, such as electricity dispatching, have been given to external bodies with regulatory functions. ${ }^{34}$ Alberta has also introduced price caps limiting peak wholesale prices. While these were

Since IRP requires forecasting future construction costs, locational demand, and the output of particular generating equipment, there is still plenty of room for forecasting error. On balance, however, utilities that use IRP are likely to have lower costs than utilities that do not.

A new technology that has made economies of scale possible with much smaller, more widely distributed generation than the long lead time megaprojects of previous years.

Electric Utilities Act, S.A. 1995, c. E-5.5, as amended.

Ibid., including the Power Pool Council and Independent Assessment Team. 
not set as absurdly low as those in California, the difference is not one of principle or kind, but merely one of degree. Alberta's wholesale electricity bid prices have bumped up against these caps and, thus have been limited by them. This has limited profitability for peaking load plants, which operate only for a relatively reduced number of hours in a year. This profitability reduction has limited new investment is such plants, which has reduced the province's total supply capacity.

Alberta's slow, protracted, and unpredictable transition process (including the bold experiment of the PPAs has caused considerable investor uncertainty, dampening investment in new generation despite rising electricity prices and shortage of supply. ${ }^{35}$ Municipal utilities in Calgary and Edmonton have been major players in buying PPAs, but private sector investment in them has been disappointing. Despite municipal initiatives in PPA auctions undertaken for taxpayer protection, and despite the participation of Edmonton's municipally owned utility, EPCOR, in joint ventures in new generation, an effectively competitive market has yet to evolve. Supply remains tight and prices remain high. This situation may correct itself if there is more new investment, but investment in this still highly politically controlled (and thus risky) industry will be attracted by prices that are consistently too high rather than too low.

Ontario, which has embarked on its own voyage toward deregulation since the enactment of the Energy Competition Act, 1998 has also created much more regulation than before over at least part of the industry.

Before this new legislation, the former Ontario Hydro had an effective monopoly over virtually all generation and transmission in the province (and over local distribution in all areas not served by municipalities), with distribution being provided elsewhere by municipally owned distribution utilities named after their cities, e.g., Toronto Hydro. Ontario Hydro had some limited regulatory authority over municipal utilities, primarily to ensure that they were well-integrated into the provincial grid, operated safely, and, on average, neither made nor lost money. This was very much light-handed regulation, compared with the level of regulatory scrutiny provided by most rate regulatory agencies. Because Ontario Hydro was owned by the province, regulation was considered unnecessary. The OEB's authority was primarily over gas utilities, not Ontario Hydro. Although the OEB had the jurisdiction to conduct public hearings about Ontario Hydro's proposed rates, it lacked jurisdiction to overrule a rate decision by Ontario Hydro, and thus the OEB's role was more advisory than regulatory.

The new legislation broke Ontario Hydro into, essentially, four new entities. As one would expect, Ontario Power Generation Inc. ("OPG") received title to all of the generation equipment, and Hydro One received title to all of the transmission and rural distribution facilities. These two companies have separate boards of directors and are intended to operate at arm's-length from each other. The Ontario Hydro grid planning and dispatch functions were given to the Independent Market Operator ("IMO"), which has its own directors representing a broad variety of interests including user groups. The 
Minister of Energy appoints all of the directors of the three companies. Finally, the Electric Safety Authority was created to carry on the electricity safety inspection role. Ontario Hydro's stranded debt was transferred to another company, the purpose of which is to hold, and, eventually, to retire that debt.

When the competitive electricity market opens in Ontario on May 1, 2002, anyone may generate electricity in Ontario provided that they have received a generation licence from the OEB. Such a licence can be granted by meeting relatively minimal requirements, and it is unnecessary to show that there is any demand for the electricity to be generated that cannot already be met by existing generation. Is this deregulation of generation? In one sense it is not because licensing was not previously required. Thus a company that wanted to generate electricity for its own use (and not for sale to Ontario Hydro's customers), could do so without obtaining a licence from anyone. In a more meaningful sense, however, the market for generation is being opened because Ontario Hydro is no longer in a position to object to the construction of new generation by its competitors, and access to the transmission system has been made more open, although there are still vigorous debates about the rates for transmission. Although Ontario has introduced more regulation, it has also introduced the opportunity for competition. Whether entrepreneurs will take advantage of the legal right to compete with OPG is uncertain given that there does not appear to be any shortage of generation capacity within the province at the present time, certain out-of-commission nuclear facilities are being refurbished, and new transmission lines are being built to increase the load that can be purchased from Quebec (a low-cost electricity producer). If substantial new generation is built resulting in excess generation capacity, given that OPG's debt servicing costs have been greatly reduced by transferring so much of its legal predecessor's former debt to the province, it may well be that many new competitors will quickly fail, resulting in little significant competition for OPG.

The new transmission company and the newly incorporated municipal electric utilities will be regulated by the OEB, with much greater scrutiny and formality (including public hearings when necessary) than before "deregulation." Formerly, the transmission activities of Ontario Hydro were not regulated, and Ontario Hydro's regulation of the municipal utilities was much simpler and more perfunctory. There was certainly no opportunity for any hearings. Nor was there any public scrutiny of proposed transmission or distribution rate increases. Clearly, then, this is an increase rather than a decrease in regulation.

This observation is not offered critically - one would expect that wires monopolies would need to be controlled to ensure that they do not abuse their monopoly powers. Again, however, the description of this restructuring as "deregulation" is misleading.

The fact that more regulatory control may be necessary during the transition from monopoly to effective competition should not cause dismay. What is dismaying is the perceived need to pretend otherwise. This merely encourages both the public and the legislators to share the misconception that deregulation is an end in itself. This may result in premature abandonment of regulatory control over what is still a monopolistic industry, the failure to privatize and break up large monopolistic enterprises, or even the inability to contemplate reintroducing appropriate regulatory controls if it becomes clear that the brave attempt to create effective competition has failed. 


\section{BAD Theory, Bad Practice?}

It is not necessary to have the right theory in order to do the right things in practice, but it helps. One is much more likely to do the right things if one knows what one is doing. Similarly, it is not necessarily dangerous to misdescribe what one is doing as "deregulation" when in fact regulation is being increased. However, communication and analysis are generally improved when we call things by descriptive rather than misdescriptive names.

If we could agree to refrain from using the word "deregulation" and refer instead to "industry restructuring to create the conditions for an effectively competitive market," how would that change our way of judging the issues? Our focus would shift from symbolic, rhetorical, and largely empty positions for or against deregulation to a discussion of

(a) whether effective competition is desirable and practicable in the circumstances; and

(b) whether the steps proposed to be introduced are likely to achieve this goal within the desired time frame.

Effective competition is not always an end in itself. ${ }^{36}$ As noted above, in a true natural monopoly with continuing economies of scale yet to be exhausted, and also with economies of scope, where investments in transmission, distribution, and generation can be planned and executed more efficiently as an integrated whole, effective competition among a greater number of less efficient units in any part of the industry would be undesirable and, in the long run, would not be practicable. The inexorable tendency to operate with fewer and larger units would be driven by the desire to reduce inefficiency. In these circumstances more competition will equal less efficiency, defined as fewer units of output per unit of input. This would be costly and wasteful.

On the other hand, true natural monopolies are rare, and the mistaken assumption that something is a natural monopoly may well result in the failure to restructure an industry that is operating inefficiently; that is, in the rising part of the U-shaped cost curve which has passed the optimal, lowest point and is moving into rising diseconomies. Alternatively, economies of scope may be overestimated, and introducing competition into generation while regulating transmission and distribution as monopolies may be the best answer. Even in this situation, however, the principle is that competition is a means to the same end, economic efficiency. It is not an end in itself.

Even under the Competition Act, R.S.C. 1985, c. C-34, s. 96(1) provides an efficiency exception to the normal merger rules. The section prohibits the Competition Tribunal from preventing a merger where the likely gains in efficiency exceed the anti-competitive effects of the proposed transaction. In a recent case, Canada (Commissioner of Competition) v. Superior Propane Inc., [2001] F.C.J. No. 455, online: QL (FCJ), the Federal Court of Appeal examined the test used in determining the applicability of the "efficiency defence." The Court found the tribunal's reliance on the "total surplus standard" to be inadequate as it failed to consider all the objectives of the Competition Act. This standard focused only on dead-weight loss, and the Court held the required standard should be "more reflective" of the different objectives of the Competition Act. 
This point is so important because Western society today is in the grip of major competition ambivalence. We profess to believe that more competition is the solution to every industry problem, without further economic analysis. We also profess to believe that if markets were trusted to operate as they should, they would operate perfectly. This is the "Economics 101" approach to social policy. It is focused on the theoretical ideal of a state of perfect competition that, like the Garden of Eden, existed before the heavy hand of regulation took away this paradise. We can return to economic paradise on earth by deregulation.

But we do not really believe this, nor do we act on it. For example, deep in our hearts we know that ten pipelines going down the same route, or ten cable television companies, or ten airlines serving the same city pairs, all in effective competition with each other is a fantasy. None of them would be able to raise the necessary capital without at least a territorial monopoly or other economic basis for satisfying providers of capital to such capital intensive industries that the capital will be employed at close to the industry's capacity. Who would finance a pipeline or an airline operating at 10 percent capacity? We know that perfect competition does not exist outside of textbooks and that usually, in many of the key infrastructures in the economy, choice is between greater and lesser degrees of oligopoly. When the real world comparison is between a regulated monopoly and, at most, an unregulated oligopoly, the range of real world choices is much narrower and must be viewed much more pragmatically.

But even the unregulated oligopoly is often a creature of controversy. Economic efficiency is not always achieved by unregulated oligopolies, and even if it were, economic efficiency is not the only economic goal of a modern economy. Societies are also concerned with allocative efficiency. ${ }^{37}$ Is the allocation of social wealth and income appropriate in a particular society? In Marxist theory, and in developing countries with a small core of extremely wealthy persons who own most of the productive capacity of the economy, the belief of the disadvantaged majority is that the owning elites and their puppet governments must be overcome by a revolution (a peaceful one, if possible). In such societies, the purpose of redistribution is merely to reduce the risk of an uprising against the economic elites' control over the state - it is trying to buy revolution insurance. In developed countries with complex social safety nets like Canada, the issue is characterized as whether the distribution is "fair"? The concern with unregulated monopolies in Canada and in similar societies is that even if a monopoly is highly efficient in terms of output per unit of input - and that is by no means is always the case - absent effective regulation, the monopoly will charge higher prices resulting in a transfer of income from captive customers to the monopoly. This transfer may be wasted in excessive salaries and bonuses for corporate management, needlessly large and overpaid work forces, inefficient and excessive capital spending, and in excessive remuneration to shareholders. Few societies, and therefore few politicians, are willing to act consistently as if they truly believed that unregulated oligopolies in industries providing essential

Allocative efficiency refers to the efficient allocation of resources in society - i.e., to avoid overinvesting in pipe by running two pipes down a street; to avoid overinvesting in facilities by goldplating, etc. It has nothing to do with an equitable, fair, or desirable allocation of wealth and income in society. That is the issue of equity, as opposed to efficiency. 
services, such as energy, ${ }^{38}$ airlines or telecommunications, are the proper blueprint for a healthy society. Most societies are far more ambivalent about markets; they love them when they work and regulate them when they don't. When providers of essential services begin to behave in ways that appear to threaten or compromise the perceived public interest, even if these are not the traditional public utilities of the last century, there will be growing pressure for political or legal intervention. Consider two recent interesting examples: Interac and Microsoft.

Interac started life in Canada as a private joint venture of banks and other large financial institutions for the purpose of developing and using common software systems for operating cheque and credit card clearing services. As the importance of Interac grew, those institutions that were not members of the "Interac Club" felt disadvantaged and agitated to join. Under pressure from the Competition Bureau, which saw Interac as having evolved into a type of modern-day public utility, Interac was compelled to open its membership to others in a manner that is analogous to a historical common carrier in the transportation field.

The recent American antitrust case against Microsoft provides another example. The case was brought because the Windows software operating system had become a type of public utility for the personal computer, now seen as an essential tool for business and personal use. Microsoft's defence was economic efficiency: it would be inefficient to break up the company, which had large economies of scope and scale. What it had done by integrating its internet browser into its operating system was to achieve greater economies of scope than had its competitors.

Without debating the merits of either side of the Microsoft case or of the Interac case, what makes them both interesting for this article is the similarity of the underlying economic arguments. A public utility can be defined as an industry that is vested with the public interest. Under that definition, the categories of public utility are not closed, and the concept is not outdated.

It also should be clear from this discussion that regulation takes many forms. Besides the traditional, wide-ranging regulators like the public utilities rate regulators found in most Canadian provinces, there are federal tribunals such as the National Energy Board, and narrow-range, indirect regulators such as the Competition Bureau and the Competition Tribunal.

Today electricity is the classic essential industry. Unlike oil and gas, electricity cannot be stored (except in a limited way, through hydro reservoirs and dams). It must be generated, dispatched, transmitted, and distributed so that supply is increased and decreased in half-hour intervals so as to be in constant balance with the fluctuating level of demand. The regulated monopoly nature of dispatch, transmission, and local distribution is not controversial, but it is by no means clear whether in all jurisdictions generation can be efficiently and effectively separated from these other functions, and then "deregulated" in order to become effectively competitive. One of the reasons that it has 
been difficult to arrive at a consensus on the merits of "deregulation" of electricity generation - apart from the vague and ambiguous nature of the word itself, which has been discussed above - is the many different ways the theory has been put into practice. Whether the theory itself is good or bad may be difficult to determine in the abstract, or even by generalizing the experience of several different jurisdictions, but the ways in which governments have attempted to put the theory into practice can more easily be judged by the results.

Let us consider as one example the California experience, discussed briefly above. This could be analogized to my hiring a taxi driver to deliver some pizzas to my home for my family dinner every Friday night from a neighbouring pizzeria. The pizzas cost $\$ 40$, and I pay the taxi driver $\$ 40$ to reimburse him for what he paid to the pizzeria and $\$ 5$ for delivering them, for a total of $\$ 45$. Next week, because of unprecedented increases in the price of cheese, pepperoni, pizza crusts, etc., the price of pizza doubles to $\$ 80$, although the taxi meters remain unchanged. My taxi arrives and the driver asks for $\$ 85$. If I were to pay him only the same $\$ 45$ as last week, on the basis that he should be required to absorb the higher costs, not only would I never again have another pizza delivery from this taxi, I may even be in danger of violent assault. I would, of course, have to pay him the entire \$85. In California the transmission utilities, whose function is delivery of electricity purchased from others who generate it, were unable to withdraw from providing service, and they were unable to raise their recoveries to the full cost of the products they were required to deliver.

This coercion against the utilities' economic interest was compelled through legislation by the California Legislature. It was very popular legislation because it kept rates "down," against the wishes, and heedless of the anguished cries, of those wicked monopolists, the electricity utilities. It was also popular because state politicians had promised the introduction of electricity "deregulation,"creating competition and subsequent lower rates. When bad planning ${ }^{39}$ for a balance of supply and demand caused a price spike, the legislation did not, according to our analogy, allow the taxi driver to charge the customer for his increased cost of buying the pizzas, and did not allow him to stop delivering them, even at an enormous loss.

One can only wonder what the California legislators were thinking when they maintained this legislation, as their way of implementing the theory of deregulation, long after it was clear that it was a failure? How could it possibly have been seen as sustainable in the long run to force distribution utilities to supply electricity so far below cost? It may have been hoped that before the utilities reached bankruptcy, the price of electricity would be reduced to levels the utilities could afford to purchase and deliver profitably, but it is not clear on what this hope was founded. It did not happen. Both of

Whatever else that can be said against vertically integrated electricity monopolies, at least they have the possibility (despite sometimes making serious forecasting errors) of planning overall supply to meet anticipated demand. This is much less likely when numerous individual generation companies. who are required by competition laws to compete with each other rather than to collude. simultaneously expand or contract generation plant capacity, each without knowing what the others will do, and what the total supply would be with and without their planned capacity change. 
the two major utilities were quickly reduced to insolvency, and the rates had to be increased.

What does the California experience tell us, as an application of the theory of deregulation, defined as removing regulatory control as a barrier to entry and replacing it with the operation of market forces? Whatever one may think of the theory, what California accomplished with this legislation was not a change in practice from regulatory control to market forces, but from market interference of a known and predictable type to market interference of an unknown and unpredictable type. The result was a change from something which, at worst, was inefficient, to something that has been catastrophic, and will continue to have high long-term costs for many years.

What were the effects of this legislation? There were several:

(a) By promising more than they could deliver through vague theories of "deregulation," legislators created a climate of public expectation that electricity rates would be reduced in absolute terms, regardless of future costs.

(b) By preventing rates from rising to meet costs for an extended period, consumers were deprived of the right price signal, which would have gradually induced them to conserve electricity with long-term strategies, such as using larger appliances at night, more energy efficient lighting, better insulation, and reflective film on windows to reduce thermal loading, etc.

(c) When the correct price signal was ultimately let through to consumers it came as a price shock, led to higher costs of reducing consumption, and may have even caused a regional or national recession.

(d) By sacrificing the equity of the numerous shareholders in the California electric utilities for what could only be short-term political gain for the legislators, the Legislature broke the regulatory pact ${ }^{40}$ under which the investment capital was supplied. This will make it much more difficult for California utilities to attract

For about a century the understanding had been that investors in utilities would be given a safe and stable place to invest their capital, in return for which their capital would be allowed only a modest return one or two percentage points above government or corporate bonds, well below the return on the typical growth stock. The reason for this pact was the same in electricity as in telephones and in pipelines. Once the capital is invested in utility facilities, whether wires, pipes or generators, it is all a sunk cost and cannot be moved or extracted from the business.

When some sort of regulatory restructuring is undertaken, investors are assured that they will be protected from erosion of their capital through the assets in which they have invested becoming stranded. Since the regulator had previously approved these investments as being prudent and necessary, and had set rates based upon this level of capital investment, it would be inconsistent to penalize investors if the government decided to change the regulatory rules of the game in the middle of the game. To do this would result in a "taking" of property, which would, arguably, require compensation. For the legal basis of this position see Manitoba Fisheries v. Canada, [1979] I S.C.R. 101 (1978), 88 D.L.R. (3d) 462; and Tener v. British Columbia (1980), 114 D.L.R. (3d) 728 (B.C. S.C.). 
equity capital in the future, raising the cost of capital. In a capital intensive industry, this will mean higher electricity prices for consumers.

(e) Investors have also been deterred by political uncertainty and distrust from investing in more generation within California. Capacity is not increasing fast enough in California, despite otherwise attractively high prices, to meet demand. Demand is still increasing rapidly because customers have not been given the right price signal for long enough to accept that these are the long-term prices and to make the investments necessary to reduce their consumption.

Whatever else we might call this California legislation, it was not deregulation. It was not an acceptance of market forces and the reduction of interference by government with the operation of markets. Quite the opposite, it was a loud proclamation that market forces would not be allowed to operate if the short-term results were not politically acceptable. The Legislature would even try to legislate market forces out of existence, all under the banner of deregulation. This has resulted in the perverse outcome of higher barriers to new entry.

One might ask why, if the legislation really hurt the wires companies, it would affect investment in generation. There are at least two answers.

First, political mistrust affects investment in all sectors of the electricity industry. If investors do not trust the government not to take or destroy their equity, they will be inclined to want to supply the Califormia market from generation investments situated outside of the state. Such plants will simply sell to the highest bidder, wherever located, rather than specifically to California. In this way they cannot become captives of the California Legislature should it again decide to start regulating the prices of generation falling within state jurisdiction. Because many of the same institutional and individual investors invest in generation and transmission assets as part of their electricity portfolios, their distrust of government (after their huge losses of equity invested in transmission, supposedly a safe "widows and orphans" stock) will be carried over into the much riskier investments in generation.

Second, some electricity holding companies own both generation and transmission assets under the same corporate family. They will perceive the recent California legislation as an attempt to do indirectly, by squeezing their transmission utilities, what the legislature had promised in its deregulation policy it would not do directly, namely, to try to control the price of generation. This price was supposed to be determined by the market.

There may have been some concern on the part of the California Legislature that because some of these transmission companies were affiliated with generation companies, they were somehow gaming their bids into the electricity spot market. This would allow the generation companies to charge excessive prices in selling electricity to their transmission affiliates, thereby earning excessive and unregulated profits in their generation affiliates. This concern may have led to the provision in the legislation preventing transmission companies from entering into long-term hedging contracts with 
generators, even though such contracts would have reduced the risk and, when electricity prices began to rise, would have eased the pain of the transmission companies. Legislation forcing all electricity transactions through the spot market would have given this market more liquidity and allowed it to operate more efficiently, but at the cost of greater price volatility and investment risk.

Gaming bids (rather than bidding competitively) are only possible (absent the criminal activity of bid rigging) where there is insufficient competition among generators bidding into the grid. In that case generators are able to use what is referred to in antitrust law as "conscious parallelism" to enable one competitor to lead and another to follow, whether by bidding in or withholding capacity in order to charge higher than competitive market prices. There are three generic strategies for defeating gaming. One is to try to increase the number of bidders through imports of electricity from adjacent jurisdictions, market conditions, and transmission intertie capacity permitting. Another is to require sufficient divestiture of generation assets, before market-opening, to create a large enough number of more or less equally strong generation bidders for all daily time periods so as to make gaming too complex and confusing to be an effective strategy. The third is to ensure that supply is not so tight that any supplier can drive the price up by withholding a small percentage of capacity.

Without adequate supply and a sufficient number of strong bidders, restructuring the industry from a regulated monopoly to an unregulated oligopoly engaged in gaming the market may leave consumers in a worse position. It may reduce economies of scope and scale, while permitting entirely legal bidding practices that effectively inflate prices above market levels.

It is appropriate to deal with concerns about such bidding practices before the legislated competitive market opening day. In California one utility, Southern California Edison, was required by the California Public Utilities Commission to divest no less than 50 percent of its $10,000 \mathrm{MW}$ in-state fossil fuel capacity. It sold the entire $10,000 \mathrm{MW}$, roughly equal to the entire generation capacity of the province of Alberta. Edison thereby increased the competition for itsel $\mathrm{f}^{\prime \prime}$ within California, but at the same time, reduced its exposure to the California market. This withdrawal suggests investor confidence that the California restructuring would employ good theory and good practice was low before the recent deterioration of the state's electricity industry. (One sees parallels to this situation in Alberta, where TransAlta was reluctant to invest in new generation in Alberta, but developed a massive cogeneration plant in Sarnia, Ontario, and undertook large scale investments outside Canada, in New Zealand.) If the California legislators thought, after market-opening, that the bidding system was being gamed as a consequence of too few competitors, the effective solution would have been to increase imports and, if necessary, require more divestiture of generation. Driving transmission companies to the brink of bankruptcy was counterproductive.

4 The capital earned by selling these assets could then be invested elsewhere, reducing the risk to the company that deregulation theory would be misapplied in practice, leading to a serious erosion is share values. 
In contrast, Ontario is proposing to open its markets to competition and then gradually cause OPG to "decontrol" - not the same as divest - its generation assets. The timetable for this has two components: a four-year timetable for fossil plant capacity and a ten-year timetable to decontrol fossil, nuclear, and plant capacity (the nuclear plants generate roughly half the electricity in the province). Within these timetables, OPG is supposed to decontrol 4,000 MW or 65 percent of Tier 2 (fossil) capacity within forty-two months of market-opening and 65 percent of Tier 1 and Tier 2 capacity. However, there is no official definition of "decontrol." It does not necessarily mean divestiture or that term would have been used. It may mean leasing, as it did with the deal to lease some of OPG's nuclear generation capacity to British Energy. This was the first of OPG's generation assets to be decontrolled.

A lessee of a plant may not have the incentive to bid the generation of the plant at a lower price than other bidders of that type of generation. Much depends upon the terms of the lease and the type of generation. The terms of the lease to British Energy, and the formulas for sharing the electricity price risks and rewards between the parties, have not been disclosed.

If the California experience is any indication, creating a sufficient number of effective competitors before market-opening is essential to avoid strategic bidding by one or a few market dominant players. This is not part of the Ontario restructuring plan. The full timetable for "decontrol" in Ontario is ten years after market-opening. It is not clear what decontrol means. Thus there is likely to be a long period, perhaps a decade or more, before Ontario will see effective competition from a number of strong bidders into the grid.

The Ontario government has been very pleased about the announcement of large new plants (yet to be constructed), such as the one by TransAlta at Sarnia. To the extent that such plants give their customers a cost-effective choice to OPG, they can be seen as a good thing. But are they really "competition" to OPG or merely load diversion? Their output is usually contracted primarily, if not entirely, to one specific large customer or a few large customers in a small geographic area. They are not merchant plants intended to compete by bidding power head-to-head with OPG into the grid. Even load diversion would be a blessing in Alberta, where it would help to meet a tight supply situation. But Ontario will, when its nuclear refurbishing plan is completed, have little or no shortage of capacity using OPG generation alone at forecasted demand for several years.

It is not particularly surprising that the transition in Ontario from a century of stateowned monopoly to one of effective competition will take a decade or more to accomplish (assuming it can be done at all). Such a radical transformation of an essential service will require adjustment. Alberta does not have the state-owned monopoly issue to contend with, but it has other problems: a relatively isolated and low-traffic density transmission grid, only three substantial generation competitors, one of which controls approximately half the generation in the province, and incumbents with well-depreciated, low-cost plants with which it will be difficult for new entrants to compete with as merchant plants. 
The principal impediments to a more rapid transition to effective competition in both Alberta and Ontario are political. In Alberta the rapid breakup of generation assets through forced divestiture by the three large generation incumbents would probably have sharply decreased the share values of these three companies. This could have been characterized as a taking, requiring compensation from the public purse. On the other side of the equation, if this forced divestiture had sharply accelerated the rate of development of effective competition, resulting in lower prices, as it theoretically should, this compensation to generation shareholders would have been a small price to pay for a longterm decrease in electricity prices. Why was this not done? Again the answer is more political than legal or economic.

Politically it would have been difficult to be seen giving significant sums of money to the shareholders of electric utilities in return for requiring the sale of their assets. Many consumers believed they had, in a sense, paid for these assets through their electricity rates.

Normally, customers of a business pay only for what they consume and do not acquire any legal interest in the property of a company through purchasing the company's products. In this case an exception to this general principle was accepted by the Ministry of Energy because the utilities are rate-regulated monopolies. While the legal title to the assets remains in the company, the ministry's position was that the matter does not end there. The utilities had constructed facilities that are worth considerably more than their depreciated book values. Generators' rates to consumers had been set for decades by the Alberta Energy and Utilities Board and its predecessors using depreciation rates which in theory matched the asset consumption during the time period over which the asset was depreciated. If insufficient depreciation had been charged and the assets had been used up prematurely, consumers would have had to pay more to make up the deficiency. When the assets themselves, or the PPAs representing the market value of their output were sold, the value of this surplus should belong to customers who had overpaid for depreciation through excessive electricity rates.

Alberta decided against ordering divestiture and, instead, created an unprecedented scheme for injecting some competition at the bidding level by entities that purchased PPAs from generators. The jury is still out on whether this scheme will create effective competition.

Ordering rapid divestiture of OPG's assets would have been politically difficult in Ontario as well. In Ontario large segments of the population are still very much in favour of "public power." They see it as provincial and municipal infrastructure, like highways and water systems, to be provided by their provincial Crown corporations and municipally owned utility companies, not by the private sector. Quite apart from the potential unpopularity of privatizing OPG, the government may be reluctant to sell off the "crown jewels" because it would lose its ownership control over a multi-billion dollar enterprise that can be used as a tool of development for creating employment in megaprojects in select areas of the province. This lack of divestiture (privatization) inevitably will mean less competition in electricity generation in the province, at least in the early years. Thus 
Ontario's electricity policy appears to be to profess a belief in competition but to act on the principle that provincial government ownership of generation is more important.

Like California, Alberta and Ontario are quite ambivalent about deregulation. Deregulation is a useful political slogan because it makes the government of the day seem to be keeping up with the times. In Alberta it also appeals to the conservative voter, who believes society would be better off with smaller government. Unfortunately, eliminating regulation of an essential service that is provided in a monopoly or oligopoly industrial structure is not simple, like getting out of the sale of liquor by privatizing liquor stores, or reducing the size of government departments, or even setting an unbundled transportation rate and creating competition in the sale of natural gas. What is called electricity deregulation requires more than just eliminating bureaucratic red tape, or saving the cost of regulatory hearings - a trivially small expense as a percentage of the annual budgets of most utilities. It is giving up a large degree of political control over an essential component of an essential service to the marketplace. That is why, despite the brave talk about deregulation, few governments really trust markets to that degree.

In an effort to have it both ways, governments announce the introduction of competition and remove some minor regulatory impediments, but fail to identify or to remove the more significant barriers to competitive entry. If things don't follow the rosy script as announced to the electorate, because for some reason prices begin to rise, panic ensues. In California the Legislature simply passed a law saying that prices would not increase, regardless of costs. In Alberta prolonged uncertainty about the direction of the reforms and interference with the market price of electricity through price caps sent negative messages to investors, which deterred new investment in generation for several years. This uncertainty, together with some interference with market price signals at peak, which failed to dampen peak demand or to encourage new supply, resulted in a capacity crunch, with peak load brownouts and loss of productivity in the entire economy. Recently part of the provincial budget surplus was used, not to cut taxes as one would have expected, but to provide "rebates" to electricity customers as compensation for the higher prices. This was an unanticipated cost of deregulation, but the trend to rapidly rising prices may not yet be over for a few years.

In Ontario the Premier and the Minister of Energy, Science and Technology delayed the market-opening previously announced to be fall of 2000, the new date being May 1 , 2002. The official reason for two previous opening delays was that the market systems were not quite ready, but there was also some governmental concern that Ontario would be seen to be going down the same dangerous path as California. Ontarians were "spooked" by the electricity crisis in California. If that was the consequence of deregulation, Ontario certainly did not want it. 
Has electricity deregulation arrived in Canada? In most provinces it has not even been considered. Where it has been considered, principally in Alberta and Ontario, ${ }^{42}$ despite the political pronouncements, radical restructuring of the generation market has yet to be tried.

\section{CONCLUSIONS}

If an industry is uncompetitive only because of "regulation," then "deregulation" is all that will be required to make the industry effectively competitive. This is almost never the case. It certainly is not the case in the electricity industry. The removal of regulation would not, by itself, make the electricity market in Canada more competitive.

"Deregulation" is an incorrect and misleading term which has, unfortunately, come into vogue to describe a radical restructuring of a monopolistic or oligopolistic industry structure to make it effectively competitive. Whereas effectively competitive industry is one in which there is a sufficient number of strong participants and low enough barriers to new entry so as to ensure that none of the incumbents can exercise sufficient market power to increase prices significantly above competitive levels, and maintain such an increase for an extended period. ${ }^{43}$

Not every monopolistic industry can be made effectively competitive on a sustainable basis. If a substantial natural monopoly component remains, the industry will, after an initial period of competition, tend to revert to monopoly or, perhaps, only a small component will remain effectively competitive. If the radical restructuring of the electricity industry causes economies of scope to be lost (e.g., through reduced IRP of generation and transmission), then this efficiency loss may not be offset by any significant efficiency gain arising from the small increment of competition that may actually be achieved.

Assuming that the electricity industry in a province can be made sustainably competitive over time, there may still be large transitional costs (as have already been incurred in California and Alberta). These can be greatly increased by using Bad Theory or applying Bad Practice when introducing reforms. In that case, even if the market structure does not revert to monopoly or oligopoly, it may take many years of lower prices brought about through effective competition to recover the losses from the higher prices paid during the transition period.

Conceptual problems (Bad Theory) would include:

\$2 New Brunswick has indicated that it will gradually introduce competition at the wholesale but not at the retail level. New Brunswick Energy Policy Working Group, New Brunswick Energy Policy White Paper 2001, online: New Brunswick Energy Policy <www.gov.nb.ca/0078/Energy/> (date accessed: 21 January 2002).

43 The Competition Bureau's Merger Enforcement Guidelines, supra note 5, suggest, in most contexts, that the threshold for a "significant" price increase should be 5 percent for an "extended" period of one year. However, where the 5 percent price increase and the one year threshold do not reflect market realities, a different price increase or time period may be employed. 
- ignoring economies of scope and scale and simply assuming that because "deregulation" worked in liquor sales or the natural gas industry, it will work just as well in electricity;

- assuming that a small number of load displacement generation projects are equivalent to "competition";

- confusing minor adjustments in the regulatory apparatus of the jurisdiction with a proper analysis of barriers to entry;

- inadequate transition planning for supply and demand; and

- a focus on distribution utility restructuring (representing approximately 15 percent of the total cost of electricity to the consumer) rather than generation (the largest single cost at 70 percent).

Implementation problems (Bad Practice) would include:

- making extravagant promises to customers about the benefits of "deregulation" and then interfering with markets when keeping these promises appears unlikely;

- failure to order divestiture, or even to limit future growth, leaving in place a large monopoly or a tight oligopoly and insufficient effective competition;

- excessive delay in introduction of the reforms, resulting in prolonged uncertainty;

- attempting to legislate the "right" price or the highest politically acceptable price for electricity; and

- failure to set and to articulate any clear objectives for the proposed reforms or to follow any meaningful principles.

The politicization of regulation over an industry formerly regulated by an expert body operating at arm's-length from government creates its own problems. These include investor uncertainty, if not insecurity, over the vagaries of politics. The solution to this problem, as California is finding, is not deregulation but depoliticization by transferring authority from the legislature back to the California Public Utilities Commission. Governments may have forgotten that one of the principal reasons for creating regulatory agencies, more than a century ago, was to depoliticize such regulatory decisions in order to foster both consumer and investor confidence in the decisions of a politically neutral, quasi-judicial, and expert body.

Governments cannot by means of a simple, quick "deregulation fix," create effective competition where previously there was only monopoly or oligopoly. It takes careful analysis to identify the barriers to competitive entry, and it takes political courage to remove them. Where the principal barrier is the virtual monopoly of a large incumbent, particularly the province's own generation utility, it may be very difficult politically to 
remove this barrier to entry, in large part due to the government's own conflict of interest as both the shareholder of the utility and the regulator of the industry. Nevertheless, until this large incumbent is dismantled, competitive investment will be deterred and competition will remain weak, primarily taking the form of small-scale industrial or municipal self-generation. Such weak competitors will be unable to impose significant price discipline on the incumbent. While the government may, by pointing to the existence of more competitors in the market, achieve a public relations victory of sorts, prices may remain substantially unaffected. 